\title{
Menedzserizmus A FELSŐOKTATÁSBAN: ÉRVEK, ELLENÉRVEK, ALTERNATÍVÁK
}

\author{
KOVÁTS GERGELY
}

Budapesti Corvinus Egyetem

Az elmúlt évtizedek felsőoktatási reformjainak egyik kiemelt célja az eredményesebb intézményi működés elérése volt, amelyet a menedzsment megerősítésével kívántak elérni. A menedzserizmus azonban az egyetem diszfunkcionális müködését is eredményezte. A tanulmány alapkérdése, hogy milyen alternatívái fogalmazódnak meg a menedzserizmusnak azokban az országokban, ahol ez vált az uralkodó egyetemszervezési megközelítéssé. A cikk áttekinti a menedzserizmus kialakulásának okait és kritikáját, néhány ellenállási és reformstratégiát, valamint illusztrációként bemutat egy egyedi irányítási gyakorlattal rendelkező egyetemet, a szövetkezeti elvekre épülő Mondragon Egyetemet.

A reformjavaslatok egyike sem vágyódik vissza az elefántcsonttoronyba, és egyik sem vitatja a hatékonyság és eredményesség fontosságát. Mindegyik úgy véli azonban, hogy a menedzserizmusnál vannak jobb módok, amelyek a hatékonyság elérése mellett a közösség és az érintettek érdekeit teljesebben meg tudják jeleníteni és jobban ki tudják egyensúlyozni. Mindegyik javaslat kiemeli a döntéshozási folyamatok demokratizálásának szükségességét, ami elengedhetetlen feltétele az egyetem megújulásának.

Kulcsszavak: felsőoktatás-irányítás, autonómia, egyetemi kormányzás, menedzserizmus, szövetkezetek

One of the key objectives of higher education reforms in recent decades has been to achieve more effective institutions by reinforcing management. However, managerialism also resulted in dysfunctional functioning of the university. The basic question of the study is what alternatives to managerialism are discussed in countries where this movement has become the dominant approach to university management. The paper reviews the causes of the emergence of managerialism, its and criticisms, some resistance and reform strategies. It also provides an illustrates example of a university with a unique management approach, the University of Mondragon, which is based on cooperative principles.

None of the reform proposals has a longing for the ivory tower, and no one challenges the importance of efficiency and effectiveness. However, they all believe that there are

Levelező szerző: Kováts Gergely, Budapesti Corvinus Egyetem, 1093 Budapest, Fővám tér 8.

E-mail: gergely.kovats@uni-corvinus.hu 
better ways than managerialism to better represent and better balance the interests of the community and stakeholders, while achieving efficiency. Each proposal highlights the need for democratization of decision-making processes which is a prerequisite for the university's renewal.

Keywords: higher education governance, autonomy, university governance, managerialism, cooperatives

\section{Bevezetés $^{1}$}

2 013-ban két holland professzor kiáltványt tett közzé, amely így kezdődik: „Az egyetemet most nem a döntésekben való részvételt követelő diákok foglalták el (mint egykor az 1960-as években), hanem a menedzsment sokfejű Farkasa. A hivatásos ügyintézők exceltáblákkal, kimeneti indikátorokkal és auditálási eljárásokkal felfegyverzett, a Hatékonyság és a Kiválóság harsány indulójának ütemére menetelő zsoldoshadseregének segítségével a Farkas gyarmatosította az oktatást. A menedzsment belső ellenségnek nyilvánította az oktatókat: nem lehet megbízni bennük, úgyhogy az átszervezés, a hamarosan lejáró szerződés és az elbocsátás rémével fenyegetőzve kell állandó próbáknak alávetni őket és ellenőrizni minden lépésüket."2 (Halffman-Radder 2014: 114.)

Talán meglepő ez a kritika egy olyan országból, amely a világ egyik legfejlettebb felsőoktatásával rendelkezik: a felsőoktatási rendszereket rangsoroló U21 rangsor szerint Hollandia felsőoktatása 2013-ban a hetedik legerősebb volt a világon (2019-ben pedig a tizedik).

A fenti kiáltvány mindenesetre jól illeszkedik abba a kritikai vonulatba, amely az egyetemek társadalmi szerepének gyengülését (szűkülését), illetve az egyetem szervezetének diszfunkcionális müködését a menedzserizmus ideológiájának térnyerésére vezeti vissza. A menedzserizmus - ahogy egy korábbi írásomban megfogalmaztam - „az a folyamat, amelynek során a menedzserek mint az önállóvá váló vezetői szakma képviselői, jogot formálnak arra, hogy a szervezetek, csoportok hatékony és eredményes müködtetésével kapcsolatos döntéseket kizárólag ők hozhassák meg, és e szakértelmükre hivatkozva társadalmi (szervezeti) hatalomra tegyenek szert. [...] A menedzserizmus azonban nemcsak a menedzserek hatalmi helyzetét megalapozó ideológiát takarja, hanem azon sajátos szervezeti formákat és gyakorlati kontrolltechnikákat is, amelyek révén az ideológia és a menedzserek hatalmi fölénye a hétköznapok során folyamatosan újratermelődik/ újratermelhető (Reed 2001; Deem E Hillyard et al 2007)." (Kováts 2011: 483 - kiemelés az eredetiben.) A menedzserizmus tehát szorosan összefügg az intézmények irányításának

1 A tanulmány az NKFIH által támogatott, „Az üzleti képzés jövője” (FK 127972) című projekt keretében készült.

2 A kiáltvány 2015-ben angol nyelven is megjelent a Minerva hasábjain, illetve a kiáltvány első fele - Wessely Anna fordításában - a BUKSZ-ban is megjelent. A továbbiakban a magyar, illetve az angol verziót használom. 
és kormányzásának változásával, a működési kereteik átalakulásával, és az ezek nyomán kialakuló új vezetési eszköztárral.

Sokan írtak már arról, hogy a menedzserizmus hogyan nyer teret és alakítja át a felsőoktatás világát. Kevesebb azoknak az írásoknak a száma, amelyek kiutakat, megoldási javaslatokat, továbblépési irányokat keresnek. A tanulmány alapkérdése ebből fakad: milyen alternatívák, cselekvési lehetőségek fogalmazódnak meg azokban az országokban, ahol a menedzserizmus teret nyert? Elkerülhetőek-e a menedzserizmus árnyoldalai?

A kérdés - és a szám egészének - aktualitását a magyar felsőoktatás közelmúltban bekövetkezett és jelenleg is folyamatban lévő változása adja. A kancellári és konzisztóriumi rendszer bevezetése, az állami intézmények közalapítványi formába történő átszervezése és magánintézménnyé alakítása (modellváltás) mind a működés professzionalizálásának, a hatékonyság, a teljesítmény, a kiválóság, a versenyképesség, a szolgáltató szemlélet javításának jegyében történik. Ezek pontosan azok a célok, amelyek mentén a felsőoktatás átszervezése Angliában, Hollandiában és más nyugati országokban is zajlott, és amelyekkel kapcsolatban a menedzserizmus kritikája visszatérően megfogalmazódik.

A következőkben előbb röviden bemutatom a felsőoktatás irányítási rendszerének átalakulását, majd a menedzserizmus kritikáját. Ezt követően áttekintek néhány ellenállási és reformjavaslatot, és részletesebben bemutatok egy konkrét intézményt, a Mondragon Egyetemet is.

\section{A felsőoktatás irányításának átalakulása}

A felsőoktatás irányítási rendszerének átalakulása a felsőoktatás expanziójában gyökerezik. A hallgatói létszámok növekedésével a kereslet sokrétűbbé vált, amelyet a kínálat differenciálódása követett. A legtöbb országban nemcsak új állami intézmények jelentek meg, hanem magánintézmények is. Ezzel párhuzamosan a képzési struktúra sokszínüsége is növekedett: új képzési szintek és munkarendek, új képzési programok tömegei jelentek meg és új szolgáltatásnyújtási formák (pl. MOOC) terjedtek el. A hallgatói populáció heterogenitása is megnőtt, ami változatosabb, igényre szabottabb pedagógiai módszertanok alkalmazását tette szükségessé (ld. hallgatóközpontú tanítás). Ezt erősítette az is, hogy az expanzió hazai bázisának kifulladását követően a legtöbb ország külföldi hallgatók toborzásába kezdett, ami élénkítette a mobilitást, és globalizálta a felsőoktatást.

Az expanzióval emelkedett a felsőoktatás forrásigénye is. Ez nemcsak a tandíjjal kapcsolatos vitákat élezte ki, hanem növelte az igényt az intézmények hatékony és átlátható működésével, az elszámoltathatósággal kapcsolatban, és vitát generált a felsőoktatás társadalmi szerepéröl.

Miközben tehát a felsőoktatás társadalmi és költségvetési súlya növekedett, a szektor komplexitása is drámaian megnőtt, és ezzel az irányíthatósága is megváltozott.

A kontinentális országokban, illetve az angol föiskolai szektorban az expanziót megelőzően az állam határozta meg a felsőoktatási intézmények működésének kereteit részben a szabályozás, részben a bürokratikus koordinációs eszközök (pl. költségvetési támogatás elosztása, vezetők kinevezése) révén. Ezzel viszonylag szűk mozgásteret hagyott az intézmény vezetésének. Az oktatók, illetve az érdekeiket megjelenítő testületek befolyása - az akadémiai szabadság védelme érdekében - viszont nagy volt. Az egyetemi vezetők 
jellemzően az egyetemi oktatók érdekeit próbálták meg képviselni az állammal folytatott alkufolyamatokban, így a feszültségek elsősorban az intézmény(vezetés) és az állam között alakultak ki. (Ezt mutatja az 1. ábra bal oldala.)

$\mathrm{Az}$ angol egyetemi szektor müködése irányítási szempontból csak annyiban különbözött az 1980-as évek elején a kontinentális modelltől, hogy az intézmények nagyon nagy önállósággal müködtek, azaz a kormányzat még a kontinentális modellnél is kisebb mértékben befolyásolta az akadémiai oligarchia döntéshozását. Jellemző példa erre, hogy az egyetemek állami támogatását egy egyetemi képviselőkből álló testület (a University Grant Committee) osztotta el az intézmények között.

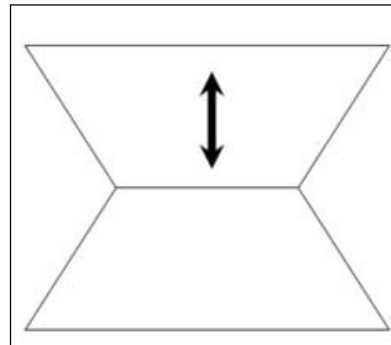

Kontinentális modell

\section{Állami \\ döntéshozók \\ Intézményi \\ menedzsment \\ Akadémiai
oligarchia \\ Akadémiai
oligarchia}

1. ábra: Az intézményirányítás modelljei. Forrás: Clark 1998 (idézi Barakonyi 2004) módosításával

Az expanzió és a növekvő komplexitás egyre inkább megkérdőjelezte e modell fenntarthatóságát. A kontinensen a bürokratikus koordináció tűnt egyre kevésbé hatékonynak, mert a kereslet változása rugalmasabb alkalmazkodást tett szükségessé. Angliában pedig az elszámoltathatóság, a hatékony és transzparens müködés volt az irányítás átalakításának fö vezérlőelve.

$\mathrm{A} z$ új irányítási modell ideológiai alapjait az új közmenedzsment (New Public Management) jelentette (Pollit 2003). ${ }^{3}$ Ebben a modellben az állam szerepe megváltozik: az intézmények közvetlen irányítása helyett ágazatirányítói, megrendelői és ellenőri szerepbe kerül. A szolgáltatásnyújtás az intézmények feladata, ebben önállóságuk (autonómiájuk) megnő, ugyanakkor felelősségük és elszámoltathatóságuk is növekszik. Annak érdekében, hogy az intézmény a rendelkezésére álló erőforrásokat a lehető leghatékonyabb módon tudja felhasználni az értékteremtésre („value for money”), növelni kell a vezetők mozgásterét („let the managers manage”).

Az elvárt outputokat és azoknak minőségi paramétereit, a teljesítés elmaradása esetén fellépő szankciókat szerződésben érdemes rögzíteni. A megfelelő ösztönzési rendszerek (pl. eredményhez kötődő jutalmazások), illetve monitoring és teljesítményértékelési rendszerek bevezetésével biztosítható, hogy az intézményvezetők valóban a számukra kitüzött célok érdekében dolgozzanak (megbízó ügynök elmélet érvényesülése). Az intézményeknek és vezetőiknek felelősséget kell vállalniuk a felhasznált adófizetői pén-

3 Mivel az 1990-es években e modell Angliában már meghatározó volt, a kontinentális felsőoktatásban viszont még nem, ezért ezt a modellt helyenként angol modellnek vagy college modellnek nevezik (pl. Barakonyi 2004). 
zekért, és vállalniuk kell az elszámoltatást („public accountability”). A szolgáltatási színvonalat folyamatosan mérni és monitorozni szükséges, amelyet standardizálás erősítésével, az adatszolgáltatások elöírása és auditok révén lehet biztosítani.

A szolgáltatók számának bővülése és ezzel a verseny növekedése lehetővé teszi a jobb szolgáltatási színvonalat azonos vagy alacsonyabb költségen is („doing more with less”), így a verseny szavatolja a források hatékony felhasználását. A versenyhelyzet szükség esetén mesterségesen, például kvázipiaci megoldások kialakítása révén is elősegíthető, ahol az állam vagy az állam nevében fellépő szereplő viselkedik megrendelőként.

Összességében tehát az új modellben az állam szerepe átalakul, az intézmények irányításába való közvetlen beleszólása csökken, az intézményvezetők mozgástere és felelőssége viszont növekszik, amelyet rendszerint az intézmény oktatóival és munkatársaival szemben kell érvényre juttatniuk. Az új modellben tehát a feszültségek jellemzően az intézményen belül, a menedzsment és a munkavállalók között jelentkezik. A belső érintetteket tartalmazó testületek szerepe csökken. (Ezt illusztrálja az 1. ábra jobb oldala.) A menedzsment és az intézmény működésének ellenőrzésére, illetve a külső érintettek elvárásainak becsatornázására több országban is kísérletet tesznek új testületek kialakítására. (Az e téren végbemenő aktuális változásokról e számban részletes áttekintést közöl Keczer Gabriella, illetve Rónay Zoltán és szerzőtársai is.)

\section{A menedzserizmus kritikája}

A menedzserizmussal szemben felmerülő ideológiai és gyakorlati kritikákat már egy korábban megjelenő tanulmányban összefoglaltam (ld. Kováts 2011). Ehelyütt ezért csak a legfontosabbak kiemelésére szorítkozom.

Az egyetem egyszerre közösség és szervezet. Közösségként elsősorban olyan szabályokat és normákat támaszt, amelyek az együttélés kereteit rögzítik, és amelyek lehetővé teszik a közösség tagjainak, hogy a rögzített kereteken belül egyéni céljaikat megfogalmazzák és megvalósítsák. A közösségnek nem szükségszerűen van célja, vagy egyidejüleg sokféle (akár egymással ellentmondó) cél is létezhet. Emiatt az egyetemet célbizonytalanság jellemezi.

Az egyetem ugyanakkor egyidejüleg szervezet is, amelyet célirányos múködés jellemez. A menedzsment az, amely a célok érdekében optimalizálja az intézmény működését.

Az új irányítási modell az egyetem szervezetszerű müködését erősíti, míg a közösségi működés jegyei a háttérbe szorulnak. Ennek oka magában a menedzserizmusban gyökerezik, amelyre éppúgy igaz az, amit Zygmunt Bauman a bürokráciáról ír: „a bürokrácia nem csupán »eszköz«, melyet éppoly könnyüszerrel lehet felhasználni egyszer kegyetlen és erkölcsileg kifogásolható, másszor pedig mélyen emberi célokra. A bürokrácia, még ha valóban abba az irányba hat is, ami felé terelik, azért leginkább olyan, mint a cinkelt kocka. Saját logikája és lendülete van. Egyes megoldásoknak kedvez, mások esélyeit inkább rontja. [...] A bürokrácia úgy van programozva, hogy az optimális megoldást keresse. Úgy van programozva, hogy ennek során nem csak hogy emberi objektumok között ne tegyen különbséget, de ember és nem-emberi objektumok között sem. Egyedül a hatékonyság számít és a költségek csökkentése." (Bauman 2001: 153-154).

A menedzserizmus saját logikája vezet a szervezet és közösség egyensúlyának felborulásához. Ez vezet ahhoz, hogy - habermasi terminológiával élve - a túlélés és 
siker érdekében célracionális módon szerveződő „rendszer” „gyarmatosítja” az „életvilágot”, azaz felülírja a társas együttmüködés alapjait képező normarendszert és értelmezési mintákat. Ennek következtében a rendszerlogika „azokon a területeken is uralkodóvá válik, ahol nem lehet helyettesíteni a kölcsönös megértésen és egyetértésen alapuló cselekvés-összehangolást" (Hidegh 2018: 81). A menedzserizmus kritikája során megfogalmazódó jelenségek e gyarmatosítási folyamat patologikus manifesztációi: a legitimációs és motivációs válság, az anómia, az elidegenedés és az értelemvesztés.

Hogyan megy végbe ez a folyamat? A szervezet céljai sokféle módon határozhatóak meg, de a menedzserizmusban a menedzsment az, amely magát feljogosítva (vagy kényszerítve) érzi a szervezeti célok megfogalmazására és képviseletére. A vezetők gyakran nemcsak az egyetem képviseletében beszélnek, hanem úgy, mintha ők maguk lennének az egyetem ${ }^{4}$ (Ørberg 2007, idézi Wright-Greenwood 2017: 45). A vezetők szerepe a célok meghatározásában nemcsak a felhatalmazásból ered, hanem abból a feltételezésböl is, hogy egyre inkább a vezetők képesek a célok kijelölésére. Ennek oka, hogy mind az intézmény, mind annak környezete egyre komplexebbé válik, így egyre több szakértelem és tapasztalat kell az intézmények vezetéséhez, és a vezetői felelősség növekedésével a menedzsment feladata is egyre bonyolultabbá válik. Ebből adódik az is, hogy a vezetés egyre kevésbé végezhető az oktatás és kutatás mellett, ami elősegíti, hogy a vezetés egyre inkább önállósodik és elkülönül a szervezet többi részétől. Ezt tükrözik a növekvő bérkülönbségek, a vezetők oktatásban-kutatásban való egyre csekélyebb szerepvállalása is (Wright-Greenwood 2017).

A közvélekedés és maga a vezetés is elsősorban a menedzsment felelősségének tekinti, hogy a szervezet eléri-e a céljait. A vezetésen ezért nagy a nyomás, hogy a szervezetet irányíthatóvá tegye, kézben tartsa. Ennek eszköze a kontroll erősítése, amelynek leginkább kézenfekvő útja a hatáskörök növelése, a döntéshozás centralizálása, a standardizáció erősítése. A célelérés megragadása méréssel, mutatószámok segítségével történik. A menedzsment szemében mindenki értékét az határozza meg, hogy mennyiben képes hozzájárulni a célok eléréséhez, azaz az indikátorokban (szükségszerűen leegyszerüsített módon) megragadott szervezeti teljesítmény javulásához.

A menedzsment kontrolligénye idővel egyre mélyebbre hatol az oktatás- és kutatás területébe (ld. az oktatási folyamatok standardizációja), így az oktatók és kutatók kontrollja fokozatosan gyengül a saját munkájuk felett, amelyeket egyre kevésbé éreznek magukénak. Helyzetüket egyre kiszolgáltatottabbnak élik meg.

A kiszolgáltatottság és bizonytalanság érzését a panoptikumként mủködő mérési és monitorozási rendszerek is fenntartják. A menedzsment a mutatószámokkal törekszik a gyengébben teljesítő szereplők és szervezetek kiszűrésére, a hatékonyság javítására. A mérés és ellenőrizhetőség folyamatossága felerősíti az intézmény szereplői közötti versengést és fokozza a teljesítménykényszert, de a létbizonytalanságot is állandósítja, hozzájárul a megosztottság növekedéséhez és a szolidaritás csökkenéséhez. Ezzel csökken annak valószínűsége is, hogy az egyetem dolgozói kollektíven lépjenek fel.

Azzal a tevékenységgel, amelynek nem érthető a célja és az értelme, s amely nem nyújtja a valódi alkotói munka érzését, egyre kevésbé lehet azonosulni. A feladatokat egyre inkább nem belső indíttatásból, hanem a külső elvárások és kényszerek miatt teljesítik a

Az eredeti angol megfogalmazás szemléletes: „university leaders claim to be speaking not just for the university but as the university (Ørberg 2007)." (Kiemelés az eredetiben.) 
munkatársak: ha az oktató a kutatási indikátoroknak való megfelelés miatt publikál, vagy az óraterhelés elérése érdekében oktat, akkor idővel meghasonlik önmagával, elveszíti belső motivációját a feladat ellátására, s azt egyre inkább külső elvárások és jutalmak (pl. karrier, státusz) fogják helyettesíteni. A kialakuló ösztönzési rendszerben felerősödik a külső motivációk szerepe, a teljesítés öncéllá válik. A teljesítménykényszer erősíti a csalási és manipulatív magatartást, aminek a menedzsment részletesebb szabályokkal és szigorúbb ellenőrzéssel igyekszik elejét venni. Ez erősíti a bürokratikus kultúrát, rontja az átláthatóságot, és fokozza a szereplők közötti bizalmatlanságot. Egyre nehezebbé válik a valódi (teljesítmény) és az értékelés kedvéért fenntartott látszat(teljesítmény) elválasztása, és az erről való őszinte beszéd. Az indikátorokban, az értékelési rendszerben nem mért teljesítmények gyakran a háttérbe szorulnak annak ellenére, hogy azok sokszor szerves részei a felsőoktatási hivatásnak, és ezek erősítik a hallgatók, oktatók közötti társas kapcsolatokat.

Mindezek a felmérésekben is tükröződnek. Egy 2016-os brit felmérésben (Times Higher Education University Workplace Survey 2016 ) a mintegy 1400 válaszadó oktató $57,5 \%$-a elégedetlen az egyetem vezetésével, $40 \%$-uk a tanszéki (intézeti) vezetéssel is. 56\%-uk szerint a munkaadó nincsen tekintettel a munkavállalók jólétére, 47\%-uk szerint a munkaterhelés aránytalan. A munka-magánélet egyensúlyát 54\%-uk érzi egészségtelennek. A juttatásokkal és a munkafeltételekkel 43\%-uk, a személyes fejlődési lehetőséggel a válaszadók 46\%-a elégedetlen. Nemzetközi összehasonlításban is az Egyesült Királyságban a legalacsonyabb az elégedettség és - a többi, menedzserizmusban élenjáró angolszász országgal együtt - a legmagasabb a stressz (Shin-Jung 2014).

\section{A menedzserizmus korrekciója: ellenállás, participáció, akciókutatás}

Milyen lehetőségek vannak a menedzserizmus kedvezőtlen hatásainak elkerülésére? Vannak-e alternatívái a kialakult irányítási modellnek? A szerzők egy része az ellenállás formáit keresi, mert úgy vélik, hogy az ellenerő révén korlátozhatóak a menedzsment túlkapásai. Mások a kialakult struktúrák kisebb-nagyobb reformjában látják a megoldást: a döntéshozási folyamat, az ösztönzési rendszer és / vagy a tulajdonosi struktúra átalakítását javasolják. Az alábbiakban a teljesség igénye nélkül néhány irányt mutatok be.

A különböző megoldások gyakori közös pontja, hogy az egyetemek társadalmi szerepének, funkciójának újragondolását sürgetik. Halfmann és Radder $(2015,2017)$ amellett érvel, hogy az új egyetem túlságosan alárendelődött a gazdasági értékteremtési logikának, nem segíti a társadalmi egyenlőtlenségek mérséklését, egyre kevésbé enged hozzáférést mindenki számára a közös tudáshoz. Az egyetem már csak az elit érdekét szolgálja, ezért azt ismét a társadalom egészét szolgáló közintézménnyé kell tenni. Ehhez új analógiákat, értelmezési kereteket kell találni, mert sem a múlt elefántcsonttornya, sem a jelen menedzserizmusa nem alkalmas erre. (Ezzel kapcsolatban lásd e számban Matolay Réka és Révész Éva tanulmányát a társadalmi vállalkozásokról, valamint Király Gábor és Géring Zsuzsa tanulmányát az egyetemek missziójáról szóló diskurzusokról.)

Halfmann és Radder szerint az egyetem megújulásának elengedhetetlen feltétele, hogy a belső és külső érintettek nagyobb beleszólást kapjanak a döntésekbe. Emellett

https://www.timeshighereducation.com/sites/default/files/best-university-workplace-survey-2016results.pdf [Letöltve: 2020.02.01.] 
a szerzők a menedzserizmussal szembeni ellenállás különböző formáit is keresik. Ezek közé tartozik például a kényszerủ hazudozás kollektív elutasítása (pl. az óraleszámolás szerint mindenki csak napi nyolc órát dolgozik), vagy az a felvetés, hogy pontosan kövessük az írott szabályokat, hogy ezzel is rámutassanak a túlszabályozás abszurditására. A szakszervezetek szerepét különösen fontosnak látják az egyetemi munkatársak megszervezésében, a szolidaritás erősítésében. Olyan kreatív stratégiák is felmerülnek, mint az ellenindikátorok alkalmazása, amelyek a menedzserizmus müködésének visszásságaira mutatnak rá ( $\mathrm{pl}$. az adminisztrációban dolgozók számának változása, bérjövedelmi egyenlőtlenségek az egyetemen belül, a legdrágább presztízsprojektek rangsora stb.), illetve a humor alkalmazása. Ennél kockázatosabb ellenálló stratégiákat is felvetnek (jogi út, sztrájk). Fontosnak látják a demokratikus jogok lehetőség szerinti kiterjesztését, mert ezek is a reform bázisául szolgálhatnak.

Bacon (2014) nem tagadja, hogy szükséges volt az irányítási rendszer átalakítása, de a változások mértékét túlzónak véli. A megoldást a kollegiális döntéshozási formák szélesebb körü alkalmazásában látja. Ezt az igényt támasztja alá a Times Higher Education fent hivatkozott felmérése is, amelyben a válaszadók 54\%-a nyilatkozott úgy, hogy nem tudja kifejezni véleményét az egyetemen. Ehhez hasonló arányok születtek a megelőző években is. ${ }^{6} \mathrm{~A}$ döntéshozásból való kiszorulás rontja a felelős egyetemi polgári (academic citizenship) elköteleződést, ami rombolja az egyetem egészét. Bacon nem hisz a kollegiális vezetés romantikus nosztalgiájában, de fontosnak véli olyan intézményesíthető (strukturális) megoldások keresését, amelyek lehetővé teszik a munkatársak döntéshozásba való érdemi (vissza)kapcsolódását, a kollegiális kultúra és a döntéshozás megerősítését. Olyan megoldásokat javasol, mint például

- a transzparencia javítása (például a vezetés, a bizottságok müködésének átláthatóbbá tétele);

- olyan vitaeljárás kialakítása és elfogadottá tétele, amelyben az alacsonyabb hierarchiaszintű egység kérheti egy magasabb szintü egységgel vagy testülettel a megbeszélést (ezzel az egységek közötti vita szervezeti elfogadottságát teremtik meg);

- facilitált konszenzusépítési eljárások kialakítása, amelyek elősegítik, hogy a felek kölcsönös megértésre, majd kompromisszumra jussanak;

- változások hosszabb időtávra időzítése, világos menetrenddel, amely kellő időt hagy a megfelelő konzultációra, és amelyet végül a kialakított megoldások formális elfogadása zár;

- szubszidiaritás erősítése, azaz a döntések azon szinthez rendelése, amely azt a leginkább hatékonyan tudja meghozni;

- a vezetők kinevezése helyett nagyobb hangsúly helyezése a vezetők választására;

- a vétólehetőség kiépítése, azaz amennyiben az egyetem vagy egy testület többsége nem támogat egy döntést, akkor az nem lép életbe. Egy ilyen lehetőség léte már elég ahhoz, hogy a vezetők a népszerütlenebb döntéseket kollegiális módon hozzák meg.

- Az osztott kormányzás (shared-governance) formáinak erősítése, amely lényegében a főbb döntéshozó testületek (board és szenátus) közötti kapcsolat kiépítését jelenti pl. vegyes bizottsági struktúra kialakításával. (Lásd részletesebben Taylor 2013.)

6 A 2015-ös felmérésben 47\%, a 2014-es felmérésben 46\% látta így. Érdemes megjegyezni, hogy a nem oktatók körében is viszonylag magas az elégedetlenek aránya: 2014-ben 34,4\%, 2015-ben 23,2\%, 2016-ban $31 \%$ volt elégedetlen a beleszólás mértékével. 
Levin és Greenwood (2016) szintén amellett szállnak síkra, hogy az egyetemek a társadalom egészét szolgáló közintézmények legyenek. A szervezetekben és a társadalomban együttmüködésre képes embereket nem lehet autoriter módon, látszatbevonásra építő egyetemeken képezni, emiatt az egyetemek demokratikus működésének erősítése elengedhetetlen. Ahogy John Stuart Mill (1977) megfogalmazta: „Nem úgy tanulunk olvasni és írni, lovagolni vagy úszni, hogy elmondják nekünk, hogyan tegyük ezeket, hanem úgy, hogy gyakoroljuk ezeket a készségeket. Ezért csak akkor tanuljuk meg a közös kormányzást a nagyobb emberi közösségekkel kapcsolatosan, ha azt kis egységekben már korábban gyakoroljuk."

A szerzők értelmezése szerint az egyetem demokratizálása nem az érintettek közötti konszenzuskényszert jelent, hanem a problémák transzparens, nyílt és valódi bevonásra épülő megvitatási folyamatát. Úgy látják, hogy a felsőoktatásban jelenleg a bevonás vagy nem érvényesül ( $\mathrm{pl}$. manipuláció van helyette), vagy csak korlátozottan érvényesül (pl. a tájékoztatás, a konzultáció, a semmire sem kötelező javaslattétel biztosítása). Ha a munkatársakat be is vonják valamilyen módon a folyamatba, az akkor is a menedzsment által, a menedzsment nézőpontjából és érdekében definiált célok és problémák megoldásába történik. A bevonás nem terjed ki sem a célok, sem a problémák körének megfogalmazására.

Megoldásként, és a valódi participáció előmozdítására, az akciókutatás eszközeinek alkalmazását javasolják. Az akciókutatás olyan facilitált folyamat, amelyben a probléma definiálása, a megoldások kidolgozása és a megvalósítás nyomon követése is az érintettek közös dialógusában valósul meg. Ennek formája lehet például az ún. kutató konferencia (search conference), amely olyan mühelymunkára épülö 1-2 napos rendezvény, amelyen az érintettek képviselői közösen értelmezik a fennálló helyzetet, a válószínű és a kívánatos jövőt, a szükséges cselekvéseket. A kidolgozott módszer előmozdítja a különböző álláspontok kölcsönös megértését és az ezen alapuló koordinált cselekvést. Levin és Greenwood (2016) bemutatják, hogy hogyan alkalmazható ez az eljárás tantervek kidolgozására, kutatási fókuszok kialakítására, a stratégiai irányok megfogalmazására, a társadalomnak nyújtott szolgáltatások körének definiálására, etikai kódex megalkotására, az oktatók értékelési és előmeneteli rendszerének kidolgozására. Ezek alkalmazása nem példa nélküli a magyar felsőoktatásban sem: hasonló participatív technikákról olvashatunk például a BGE etikai kódexének kialakításával (Géring et al. 2019) vagy a felsőoktatási jövőkép backcasting technikával történő kidolgozásával kapcsolatban (Király et al. 2016a, 2016b).

\section{A tulajdonosi és döntéshozási struktúra átalakítása}

$\mathrm{A} z$ akciókutatással kapcsolatos egyik gyakori kritika, hogy jelentősebb kérdésekben a menedzsment nem érdekelt a participatív folyamatokban. A menedzserizmus problémáját többen a döntési, és ezzel összefüggésben a problémás tulajdonosi (Wright-Greenwood 2017) és ösztönzési struktúrában látják. A menedzsmenttel szemben sem az állam, sem a külső érintettek (board) nem tudnak hatékonyan tulajdonosként fellépni, az oktatók pedig kiszorulnak az irányításból, csak munkavállalóként jelennek meg. Mivel az egyetemi müködés nehezen mérhető, így a piac sem tud egyértelmü visszajelzéseket adni a menedzsment teljesítményéröl. Így piaci környezetben, ahol az állam már csak közvetve (a távolból) irányítja az autonóm, önirányító intézményeket, a menedzsment könnyen 
vissza tud élni a helyzetével, akár az irányítás megszilárdításáról, akár a társadalmi erőforrások magáncélú hasznosításáról van szó. Ennek korlátozására sem a piaci, sem az állami tulajdonlás megerősítése nem jelent jó megoldást, mert ez azzal a kockázattal jár, hogy a kormányzat vagy a tőketulajdonos a saját, és nem a társadalom, érdekei szerint kívánja működtetni az intézményt. Az oktatói önirányítás visszaállítása pedig azzal a problémával járna, hogy az irányítás mellé nem társult valódi tulajdonosi szemlélet és felelősség - ez pedig szintén visszaélésekre adhat alkalmat.

A kiutat olyan működési keretek kialakítása jelentheti, amely a munkavállalók számára is tulajdonosi jogokat nyújt, ami az intézmények kormányzási struktúrájának újragondolásával jár. (Derényi András tanulmánya e számban áttekinti, hogy Magyarországon a müködési keretek átalakítására milyen kísérletek történtek, Szabó Tibor pedig a kancellár és rektor szerepének változását elemzi e nézőpontból.)

Boden és társai az alapítványi egyetemet (trust university) tekintik egy lehetséges opciónak, amelyet a John Lewis \& Partners (JLP) kiskereskedelmi lánc alapján képzeltek el (Boden-Ciancaneli-Wright 2011). A JLP eredetileg családi cég volt, amelynek részvényeit a tulajdonosa 1929-ben egy alapítványra ruházta át. Az alapítvány alapvető célja - a JLP alkotmánya szerint - „minden tagjainak boldogsága egy sikeres vállalkozásban való méltó és megelégedésre szolgáló alkalmazás révén”. (JLP 2017: 7.) Az alapítvány haszonélvezői a cég mindenkori munkatársai, akiket partnernek neveznek. A partnerek között a nyereséget az alapítvány kuratóriuma osztja el. A menedzsment visszaélését több tényező is korlátozza: egyrészt maguk a részvények elidegeníthetetlenek, másrészt a kuratórium felét a partnerek (azaz a munkavállalók) választják meg, harmadrészt a menedzsment és a partnerek közötti jövedelmi arány maximumát rögzítik. A szervezet számos demokratikus fórumot is müködtet. A javaslat szerint az alapítványi egyetem is hasonló tulajdonosi konstrukcióban müködhetne: az egyetem eszközei egy alapítvány tulajdonában vannak, amelynek a munkavállalók és diákok a kijelölt haszonélvezői. Tisztázatlan ugyanakkor, hogy a szerzők pontosan milyen kormányzási struktúrát képzelnek el az egyetem számára, hogyan működnének a demokratikus struktúrák (Neary-Winn 2017), például ki és hogyan választaná ki a vezetőt? Azzal kapcsolatban is sok a kétség, hogy vajon a JLP bonyolult belső kormányzási és tulajdonosi struktúrája átvihető-e egy jelentősen különböző ágazatba (Salaman-Storey 2016; Paranque-Willmott 2014).

Egy másik mintát jelenthet a szövetkezeti müködési forma. A szövetkezeti mozgalom olyan alapelvekre épül, mint nyitott szervezet és önkéntes tagság, a szövetkezetek demokratikus irányítása a tagok révén, a tagok gazdasági szerepvállalása a szövetkezetben, a szövetkezet autonómiája és függetlensége, a szövetkezetek közötti együttmüködésre való törekvés, a tágabb közösségért való felelősség. Cook (2013: 19-22) és Yeo (2015) is rámutat arra, hogy a szövetkezeti mozgalom alapelvei és a felsőoktatási intézmények tradicionális értékei között számos hasonlóság található, hiszen a felsőoktatási intézményekhez is bárki csatlakozhat hallgatóként, oktatóként, aki megfelel az elöírt követelményeknek, a felsőoktatási intézmények számára is fontos az autonómia és a többi felsőoktatási intézménnyel való együttműködés. Mára a társadalmi szerepvállalás (harmadik misszió) erősítése is elfogadott értéknek tekinthető. A demokratikus irányításnak is számos hagyománya létezik, amelynek alapját az jelenti, hogy a tudományos, illetve ezzel összefüggő oktatási-kutatási kérdésekben a tudományos közösségnek kell döntenie. A demokratizmus nemcsak a felsőoktatási intézmények irányításával kapcsolatban értelmezhető, hanem azok pedagógiai megközelítésével kapcsolatban is. A hitelesség 
megkívánja az intézmények (szervezeti keretek) és a pedagógia összhangját. Bár ennek elemzésére e cikkben nem térek ki, úgy vélem, hogy a demokratikus irányítási formák kedvezőbb feltételt teremtenek a reformpedagógiai irányzatoknak vagy a kritikai pedagógiának (pl. Freire) (ld. Saunders 2017).

A JLP-hez hasonló alapítványi struktúrával ellentétben azonban a világon több szövetkezeti egyetemet találhatunk, így például a spanyol Mondragon Egyetemet, a kolumbiai Universidad Cooperativa de Colombiát, ${ }^{7}$ a kenyai szövetkezeti egyetemet ${ }^{8}$ és a mexikói Unicoopot. ${ }^{9}$ Ezek közül a legismertebbnek tekinthető Mondragon Egyetem működését mutatom be az alábbiakban.

\section{Egy figyelemfelkeltő példa: a Mondragon Egyetem}

A Mondragon Egyetem a Mondragon Corporation tagjaként működik Spanyolország egyik legfejlettebb régiójában, a baszk autonóm közösségben. A Mondragon csoportot egy spanyol katolikus pap, José María Arizmendiarrieta alapította 1956-ban nem pusztán üzleti vállalkozásként, hanem olyan társadalmi kísérletként, amely a demokratikus működést, a szolidaritást, az együttműködést, az önfenntar tó működést, az innovációt és a munka központi szerepét kívánja széles körben elfogadott értékekké tenni.

A Mondragon csoport jelenleg Spanyolország hetedik legnagyobb üzleti csoportja, amelynek 2017-ban a teljes bevétele 12 Mrd euró, munkavállalóinak száma pedig 80 ezer fő volt. A csoport a világ minden kontinensén jelen van. A csoportot 2017-ben 266 tagszervezet alkotta, amelyek négy területen müködtek: pénzügyi szolgáltatások, gyártás, kiskereskedelem és tudásipar. ${ }^{10}$

A Mondragon csoport sajátossága, hogy a világ egyik legnagyobb és legsikeresebb dolgozói szövetkezete. Alapvető struktúráját a szövetkezetek jelentik: a 266 tagszervezetből 98 szövetkezeti formában működik. Egy szövetkezet tulajdonosai maguk a munkavállalók, az egyes szövetkezetek így nagy önállósággal rendelkeznek. (A Mondragon csoport működésének részletes leírását lásd Lafuente 2012.)

A tagszövetkezetek müködését tíz alapelv határozza meg (lásd a 2. ábrát): 1. nyitott tagság; 2. demokratikus szerkezet; 3. a munka szuverenitása; 4. a tőke eszközjellege, alárendelt szerepe; 5 . önigazgatás, részvétel a vezetésben; 6. jövedelmi szolidaritás; 7. kooperáció; 8. társadalmi szerepvállalás; 9. egyetemes jelleg és 10. az oktatás-képzés fontossága.

Az elvek természetesen átfedésben vannak a szövetkezetek korábban bemutatott általános elveivel, ezért a mondragoni elvek részletes bemutatása helyett (lásd ezt Hunyadi 2003) csak néhány elemet emelek ki.

A munka szuverenitása például azt jelenti, hogy a szövetkezetek lemondanak a fizetett munkaerő (bérmunka) alkalmazásáról, és csak tulajdonos-önfoglalkoztatók kezébe helyezik a szövetkezetek ellenőrzését, ami a demokratikus irányítás alapját jelenti. Ennek megfelelően a jövedelemfelosztásban is elsősorban a munkaerő részesül. A jövedelmi

7 https://www.ucc.edu.co/en/Paginas/inicio.aspx [Letöltve: 2020.02. 01.]

8 https://www.cuk.ac.ke/ [Letöltve: 2020. 02. 01.]

9 http://www.unicoop.mx/u/index.cfm [Letöltve: 2020. 02. 01.]

10 https://www.mondragon-corporation.com/en/about-us/economic-and-financial-indicators/ [Letöltve: 2020.02.01.] 


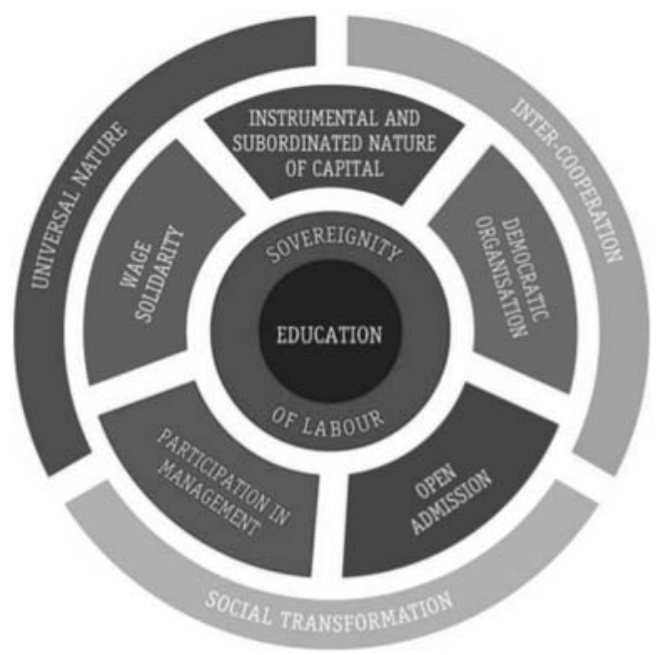

2. ábra: A Mondragon Corporation alapelvei. Forrás: Lafuente 2012

(Az ábra feliratai magyarul: OPEN ADMISSION = nyitott tagság; DEMOCRATIC ORGANISATION = demokratikus szerkezet; SOVEREIGNITY OF LABOUR $=\mathrm{a}$ munka szuverenitása; INSTRUMENTAL AND SUBORDINATED NATURE OF CAPITAL $=$ a tőke eszközjellege, alárendelt szerepe; PARTICIPATION IN MANAGEMENT = részvétel a vezetésben; WAGE SOLIDARITY = jövedelmi szolidaritás; INTERCOOPERATION = kooperáció; SOCIAL TRANSFORMATION = társadalmi transzformáció; UNIVERSAL NATURE = egyetemes jelleg; EDUCATION = oktatás-képzés)

szolidaritás azt jelenti, hogy a legalacsonyabban és a legmagasabban fizetett tag jövedelme közötti különbség legfeljebb hatszoros lehet. (Viszonyításul: a JLP-nél ez 75-szörös volt.) A szövetkezeti formában való működés a társadalmi átalakulás eszköze (társadalmi transzformáció), a szövetkezet pedig a gazdasági és társadalmi folyamatokba történő személyes és közösségi integráció kereteinek megteremtője. Az oktatás kiemelt szerepe azt jelenti, hogy a szövetkezetek folyamatosan támogatják a tagok tanulását, és az ennek szervezeti keretét jelentő iskolákat és egyetemeket.

A Mondragon Egyetemet, amelyet 1997-ben ismert el a baszk parlament, a Mondragon csoport három oktatási szövetkezete hozta létre. Jelenleg az egyetemnek négy kara van, zárójelben az alapítás éve szerepel: Műszaki Kar (1943), Üzleti Kar (1960), Bölcsész- és Neveléstudományi Kar (1976) és Gasztronómiai Kar (2011). Az egyetem hallgatóinak száma 2017-2018-ban 4800 fö volt, emellett az egyetem körülbelül évi 5000 főnek nyújtott továbbképzést. Az oktatók száma 461 fő volt, az adminisztrációban pedig 132 fő dolgozott. (Figyelemre méltó, hogy az adminisztrációban dolgozók aránya a teljes létszámhoz képest milyen alacsony!) Bevételeinek nagysága 2016-2017-ben 72 millió euró volt, amelynek 41\%-a tandíjakból, 16\%-a állami támogatásból, 30\%-a kutatási megrendelésekből, $13 \%$-a pedig pályázatokból származott.

$\mathrm{A} z$ egyetem az U-multirank nemzetközi rangsor szerint kiváló (A kategóriás) értékeléssel rendelkezik a tudástranszfer és a regionális kapcsolódás indikátoraiban, és szintén kiemelkedik a nemzetközi mobilitás és a külső kutatási bevételek arányát tekintve. ${ }^{11}$

11 https://www.umultirank.org/study-at/mondragon-university-rankings/ [Letöltve: 2020. 02. 01.] 
A Mondragon Egyetem szövetkezeti formában müködik: az alapító karok eredetileg szövetkezetek voltak, és az egyetem létrejötte után is megtartották szövetkezeti formájukat. ${ }^{12}$

A szövetkezet minden munkavállalójának két év munkaviszony után nyílik lehetősége arra, hogy a szövetkezeti tagdíj megfizetésével a szövetkezet teljes jogú tagjává váljon. A tagdíj összege egyenlő az adott szövetkezetben szerezhető éves jövedelem legalacsonyabb szintjével (Wright-Greenwood-Boden 2011). Ennek megfizetésére többféle lehetőség áll rendelkezésre. A tagoknak a tagdíj révén közvetlen anyagi érdekeltsége keletkezik a szövetkezet sikerességében, és ez egyben megalapozza a döntéshozási folyamatokban való részvételét is. A szövetkezetből történő kilépés esetén a tag ezt a tőkealapot az addig felhalmozódó nyereséggel együtt (méltányos kamattal) visszakapja.

Ha a szövetkezet nyereséges, akkor a nyereség egy részének terhére a tagok az éves bérük 3-6\%-át kaphatják meg nyereségként (ez az alkalmazottak tőkealapjába kerül), a nyereség egy másik része pedig egy szolidaritási alapba kerül. Ha a szövetkezet veszteséges, akkor azt vagy a tagi hozzájárulásokból fedezik, vagy más szövetkezetek adnak átmeneti támogatást (a szolidaritási alapjuk terhére), vagy pedig csökkentik a fizetéseket. Az üzleti karon például a 2008-as gazdasági válság időszakában a tagok fizetését az eredeti összeg 80\%-ára csökkentették a veszteségek miatt (Wright-Greenwood-Boden 2011; Matthews 2013). A bérarány a Mondragon Egyetemen is rögzített: 2017-2018-ban a legalacsonyabb bér bruttó 21000 euró, a legmagasabb 70500 euró volt. ${ }^{13}$

A Gasztroökönómiai Kar kivételével az egyetem mindegyik kara jogilag önálló szövetkezet formájában müködik. Mindegyik kar/szövetkezet élén a dékán áll, aki egyben a szövetkezet ügyvezető igazgatója is. A dékán feladata az oktatás-kutatás fejlesztése, a karral kapcsolatos menedzsment feladatok ellátása, valamint az egyetemi stratégiában közösen rögzített célok elérésének biztosítása. Az egyetem olyan másodlagos szövetkezet, amelynek tagjai a kari szövetkezetek és más szövetkezetek.

A kari szövetkezetek legfontosabb döntéshozó szerve a közgyülés (General Assembly), amelyben 1/3-1/3 arányban vannak jelen a kar munkavállalói (ún. work members), a hallgatók (user members) és a külső partnerek (collaborating members; ők lehetnek társszövetkezetek vagy a Mondragonon kívüli együttműködő partnerek). A Műszaki Kar közgyülésén például mindegyik csoportot 289 fó képviseli, akiket demokratikusan választanak. ${ }^{14} \mathrm{~A}$ közgyülésen mindenkinek egy szavazata van. A közgyülés évente szavaz az üzleti tervröl, a beruházási döntésekröl, a bérezési gyakorlatról és más nagy horderejü témáról.

A kari közgyưlés egy kisebb létszámú, 12 tagú irányító testületet (Governing Board) bíz meg az elfogadott négyéves tervek megvalósulásának folyamatos (havi szintü) ellenőrzésével. A testület dönt az új oktatók felvételéről és a szövetkezeti tagok befogadásáról, és e testület nevezi ki a dékánt is. A testületben 4-4 fő képviseli a hallgatókat, a munkatársakat és a külső partnereket.

A kari operatív menedzsment feladatokat a végrehajtó testület (Executive Board) látja el, amelyben a dékán és a különböző igazgatók kapnak helyet. E testületeket a társadalmi

\footnotetext{
12 A Gasztroökonómiai Kar technikai okból alapítványként müködik, mert a kar épülete állami támogatásból épült meg.

13 https://www.mondragon.edu/en/meet-mu/transparency-portal/staff [Letöltve: 2020. 02. 01.]

14 https://www.mondragon.edu/en/faculty-of-engineering/organigram [Letöltve: 2020. 02. 01.]
} 
testület (Social Council) egészíti ki, amely lényegében az egyetem munkavállalóinak és doktori hallgatóinak folyamatos érdekképviseletét és tájékoztatását látja el. Számos területen rendelkezik véleményezési joggal. A testület elnöke az irányító testület egyik tagja.

$\mathrm{A} z$ egyetemi szinten hasonló testületek működnek, amelyek hatáskörmegosztása is hasonló, de összetételük különböző. Az egyetemi közgyűlésben a karokat 30 tag képviseli, az együttműködő partnereket (pl. városvezetés, Mondragon csoport) 6 fö, a munkatársakat (az egyetemszintű szövetkezetet) pedig egy fö. A hallgatóknak nincs önálló képviseletük, a kari képviselők között kaphatnak helyet. Az egyetemi irányító testületbe 12 tagot választanak a karok és 5-öt a külső partnerek. A külső partnereknek nincsen anyagi érdekeltségük az egyetem müködésében, elsősorban a közjót képviselik. A külső partnerek képviselőit az egyetemi közgyủlésnek és az egyetem irányító testületének is jóvá kell hagynia. Az egyetemi végrehajtó testület tagjai közé tartozik a rektor és a rektorhelyettes, a karok dékánjai, valamint a különböző igazgatók. Mivel a karok nagy önállósággal rendelkeznek, önálló stratégiákat és terveket dolgoznak ki, ezért a rektor szerepe elsősorban a koordináció megteremtése, a kari törekvések harmonizációja, az egyetem külső képviselete (Wright-Greenwood-Boden 2011; Matthew 2013).

Mind a kari, mind az egyetemi testületekbe a tagokat demokratikus úton választják.

Boden (2019) úgy látja, hogy a munkatársak munkaidejük 20-40\%-át töltik konszenzuskereső megbeszéléseken, testületi üléseken, amely viszont a döntések széles körü elfogadottságában, megértésében és a végrehajtásban térül meg. Boden véleménye szerint a döntéshozási struktúra nem tér el radikálisan a legtöbb kontinentális felsőoktatási intézmény gyakorlatától, ezeket a kereteket viszont a Mondragon Egyetemen a szövetkezeti kultúrával és értékrenddel töltik meg. Ez annak is köszönhető, hogy a Mondragon Egyetem mélyen beágyazódik a Mondragon csoportba, amelyek elvárják és vissza is igazolják a szövetkezeti működés helyességét. A Mondragon tehát egy tágabb szervezeti (és regionális) ökoszisztéma szerves részeként létezik, ami miatt a modell másolhatósága korlátozott.

Ez nem jelenti azonban azt, hogy az elemeit ne lehetne mintaként és inspirációs forrásként használni új kormányzási modellek kialakítása során (Wright-Greenwood-Boden 2011). Az angol szövetkezeti mozgalom már majdnem egy évtizede, az angol felsőoktatási szolgáltatói piac megnyílása óta foglalkozik a szövetkezeti egyetem alapításának lehetőségével (Neary-Winn 2019), amelyet éppúgy elképzelhetőnek tartanak zöldmezős beruházásként, mint egy más létező egyetem belülről vagy felülről való átalakításával (Cook 2013).

Szembetűnő, hogy a menedzserizmus egyik bemutatott reformalternatívája sem vágyódott vissza az elefántcsonttoronyba, és egyik sem vitatta a hatékonyság és eredményesség fontosságát. Mindegyik úgy vélte azonban, hogy vannak jobb módok, amelyek a hatékonyság elérése mellett a közösség és az érintettek érdekeit teljesebben meg tudják jeleníteni és jobban ki tudják egyensúlyozni, mint ahogyan azt most a menedzserizmus teszi. Mindegyik kiemelte a döntéshozási folyamatok demokratizálásának szükségességét, és ennek kereste módszertani vagy strukturális kereteit. Ez elengedhetetlen feltétele az egyetem megújulásának, a „modellváltásnak”. 


\section{IRODALOM}

Bacon, E. (2014) Neo-collegiality: Restoring Academic Engagement in the Managerial University. London, Leadership Foundation for Higher Education.

Barakonyi K. (2004) Egyetemi kormányzás. Merre tart Európa? Közgazdasági Szemle, Vol. 51. No. 6. pp. 584-599.

Bauman Z. (2001) Modernitás és holokauszt. Budapest, Új Mandátum.

Boden, R. (2019) Europe: Spain: Space of Hope. Democratic Leadership in a Workers' Cooperative University in Spain. In: J. Jameson (ed.) International Perspectives on Leadership in Higher Education: Critical Thinking for Global Challenges. London, Routledge. pp. 46-57.

Boden, R., Ciancanelli, P. \& Wright, S. (2011) Trust Universities? Governance for Postcapitalist Futures. Journal of Co-operative Studies, Vol. 45. No. 2. pp. 16-24.

Clark, B. R. (1998) Creating Entrepreneural Universities: Organisational Pathways of Transformation. Oxford, Pergamon. Idézi Barakony 2004.

Cook, D. (2013) Realising the Co-operative University. A Consultancy Report for the Cooperative College. Elérhető: https://coopuni.files.wordpress.com/2013/12/realising-theco-operative-university-for-disemmination.pdf [Letöltve: 2020. 02. 01.]

Géring Zs., Győri Zs., Csillag S. \& Szegedi K. (2019) Codes of Ethics in Higher Education. Methodolical Insights from a Culture Development Project. Ethical Perspectives, Vol. 26. No. 1. pp. 59-90.

HalfFMan, W. \& Radder, H. (2014) A megszállt egyetemből legyen újra közintézmény! BUKSZ, Vol. 27. No. 1-2. pp. 114-120.

Halffman, W. \& Radder, H. (2015) The Academic Manifesto: From an Occupied to a Public University. Minerva, Vol. 53. No. 6. pp. 165-187. DOI: 10.1007/s11024-0159270-9.

Halffman, W. \& Radder, H. (2017, eds) International Responses to the Academic Manifesto: Reports from 14 Countries. Social Epistemology Review and Reply Collective. Special Report. pp. 1-76.

Hidegh, A. (2018) Az emberierőforrás-menedzsment habermasi kritikája. Replika, Vol. 106-107. No. 1-2. pp. 77-96. DOI: 10.32564/106-107.5.

Hunyadi A. (2003) Az „etikus társadalmi szerződés” baszkföldi példája: a Mondragon Szövetkezeti Csoport. Regio, Vol. 14. No. 3. pp. 37-67.

JLP (2017) The Constitution of the John Lewis Partnership. Partnership Day 2017 edition. Elérhető: https://www.johnlewispartnership.co.uk/content/dam/cws/pdfs/about-us/ourconstitution/john-lewis-partnership-constitution.pdf [Letöltve: 2020. 02. 01.]

Király G., Géring Zs., Csillag S., Gáspár T. \& Köves A. (2016) Rendszermodellezés a felsőoktatásról: Jelentésadás egy részvételi folyamatban. Socio.bu, Vol. 6. No. 3. pp. 66-90.

Király, G., Géring, Zs., Csillag, S., Köves, A. \& Gáspár, G. (2016) Constructing Future Visions about Higher Education with Participatory Methods. In: J. Huisman $\&$ M. Tight (eds) Theory and Method in Higher Education Research. Volume 2. Bingley, Emerald Group Publishing, Ltd. pp. 95-114.

Kováts G. (2011) Menedzserizmus az angol felsőoktatásban. Educatio, Vol. 20. No. 4. pp. 482-497.

Lafuente, J. L. (2012) The Mondragon Cooperative Experience: Humanity at Work. https://www.mixprize.org/story/mondragon-cooperative-experience-humanity-work [Letöltve: 2020.02.01.] 
Levin, M. \& Greenwood, D. (2016) Creating a New Public University and Reviving Democracy. Action Research in Higher Education. Berghahn, New York and Oxford.

Matthews, D. (2013) Inside a Cooperative University. Times Higher Education. https://www.timeshighereducation.com/features/inside-a-cooperativeuniversity/2006776.article [Letöltve: 2020. 02.01.]

Mill, J. S. (1977) The Collected Works of John Stuart Mill, Volume XVIII - Essays on Politics and Society Part I (On Liberty). https://oll.libertyfund.org/titles/mill-the-collectedworks-of-john-stuart-mill-volume-xviii-essays-on-politics-and-society-part-i [Letöltve: 2020. 02. 01.]

Neary, M. \& Winn, J. (2017) Beyond Public and Private: A Framework for Co-operative Higher Education. Open Library of Humanities, Vol. 3. No. 2. pp. 1-36. https://doi. org/10.16995/olh.195.

Neary, M. \& Winn, J. (2019) The Coopeartive University Now! In: T. Woodin \& L. SHaw (eds) Learning for a Co-operative World: Education, Social Change and the Cooperative College. London, UCL Institute of Education Press. pp. 169-186.

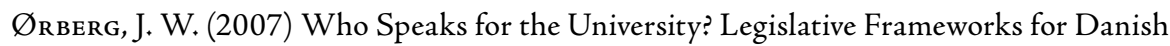
University Leadership 1970-2003. Working Papers on University Reform no. 5. Copenhagen, Danish School of Education. Idézi Wright \& Greenwood 2017.

Paranque, B. \& Willmott, H. (2014) Cooperatives-Saviours or Gravediggers of Capitalism? Critical Performativity and the John Lewis Partnership. Organization, Vol. 21. No. 5. pp. 604-625. DOI: 10.1177/1350508414537622.

Pollit, C. (2003) The Essential Public Manager. Maidenhead, Open University Press.

Salaman, G. \& Storey, J. (2016) A Better Way of Doing Business? Lessons from the John Lewis Partnership. Oxford, Oxford University Press.

Saunders, G. (2017) Somewhere between Reform and Revolution: Alternative Higher Education and 'the Unfinished'. In: J. Winn \& R. Hall (eds) Mass Intellectuality and Democratic Leadership in Higher Education. Perspectives on Leadership in Higher Education. London, Bloomsbury. pp. 157-170.

Shin, J. C. \& Jung, J. (2014) Academics Job Satisfaction and Job Stress across Countries in the Changing Academic Environments. Higher Education, Vol. 67. No. 5. pp. 603-620. DOI: $10.1007 / \mathrm{s} 10734-013-9668-y$.

TAYlor, M. (2013) Shared Governance. Higher Education Quarterly, Vol. 67. No. 1. pp. 80-94. DOI: $10.1111 /$ hequ. 12003.

Wright, S. \& Greenwood, D. (2017) Universities Run for, by, and with the Faculty, Students and Staff Alternatives to the Neoliberal Destruction of Higher Education. Learning and Teaching, Vol. 10. No. 1. pp. 42-65. DOI: 10.3167/latiss.2017.100104.

Wright, S., Greenwood, D. \& Boden, R. (2011) Report on a Field Visit to Mondragón University: A Cooperative Experience / Experiment. Learning and Teaching, Vol. 4. No. 3. pp. 38-56. DOI: 10.3167/latiss.2011.040304.

Yeo, S. (2015) The Co-operative University? Transforming Higher Education. In: T. Woodin (ed.) Co-operation, Learning and Cooperative Values. London, Routledge. pp. 131-146.

A cikk a Creative Commons Attribution 4.0 International License (https://creativecommons.org/licenses/ by/4.0/) feltételei szerint publikált Open Access közlemény, melynek szellemében a cikk bármilyen médiumban szabadon felhasználható, megosztható és újraközölhető, feltéve, hogy az eredeti szerző és a közlés helye, illetve a CC License linkje és az esetlegesen végrehajtott módosítások feltüntetésre kerülnek. (SID_1) 